\author{
Akiko Kuroda, Kanae Suzuki \\ Yashima Gakuen University, University of Tsukuba \\ k.akiko2130@gmail.com, kanae@,slis.tsukuba.ac.jp
}

\title{
Promoting School Libraries' Support of Investigative Learning in Art Classes: A Case Analysis
}

\begin{abstract}
In this study, 25 reports of art classes were surveyed to analyze school libraries' ability to support investigative learning in art classes and to propose methods for doing the same. The results suggest that school libraries can support all stages of students' investigative learning in art classes, including those where students learn about ideas or concepts of the work. The most frequently reported activity was utilizing different types and characteristics of media. In collaboration with art teachers, school libraries are required to work to prepare and support students' access to various media, in order to deepen their investigative learning.
\end{abstract}

Keywords: investigative learning, inquiry, school library, art classes

\section{Introduction}

In the midst of an unprecedented global crisis, a variety of art activities (e.g., the \#tussenkunstenquarantaine trend) that connect people with others and society have spread, and the importance of art has been reaffirmed. Children are now expected to have the ability to create solutions to various problems, and the importance of STEAM (Science, Technology, Engineering, Art, and Math) education and investigative learning has been noted.

Art education aims to nurture expression, imagination, and a creative attitude through the understanding of objects and events. Efland (2002) argues that the more views of art found in the cognitive domain, the more diverse art can be understood and appreciated. This suggests the importance of investigative learning in art education. This study focuses on investigative learning in art education.

\section{Literature Review}

Looking at the concept of art education in an international program is a good place to begin an inquiry such as this. The International Baccalaureate (IB) program, which provides a universal university entrance qualification and transcript for arts education without being biased by any one country's system or content, is ideal for this purpose. In the IB Middle Years Programme, aimed at students aged 11-16, the concept of art education is based on the idea that "involvement in the arts encourages students to understand the arts in context and the cultural histories of 
artworks, supporting the development of an inquiring and empathetic world view" (International Baccalaureate, 2021a). This reinforces the importance of deepening students' understanding and investigative learning through art education. Similarly, in the IB Diploma Programme, for students aged 16-19, "each subject is designed to foster critical, reflective and informed practice, help students understand the dynamic and changing nature of the arts, [and] explore the diversity of arts across time, place and cultures" (International Baccalaureate, 2021b).

Looking at art education in Japan, the curriculum for junior high schools includes the goals of "understanding the formative perspectives of objects and events, and being able to express oneself creatively by devising methods of expression" and "thinking about the goodness and beauty of formative arts, the intentions and devices of expression, and the functions of art" (Ministry of Education, Culture, Sports, Science and Technology [MEXT], 2017). Similarly, the curriculum for senior high schools aims to "deepen understanding of specialized and diverse content related to art and enable students to express themselves in original ways" (MEXT, 2018). Thus, art education aims to nurture expressive power, imagination, and a creative attitude through the understanding of objects and events. This is a point in common with the concepts of the IB curriculum.

Investigative learning leads to a deeper learning of art. Commentary on the Courses of Study for art classes in Japan (Ministry of Education, Culture, Sports, Science and Technology, 2017) emphasizes the need for students to investigate. There is also the statement, "In conducting investigative learning, it is necessary to make effective use of museums, libraries, etc., provide opportunities for presentations, and conduct them in a coordinated way." However, it does not explain how to support students' investigation process.

A questionnaire survey of school libraries indicated that they provide little support for art studies, but more than $80 \%$ of them do have art-related library materials, classified as "paintings" or "crafts," suggesting that school libraries can support art classes more actively than they currently do (Kuroda et al., 2015). With this in mind, it is necessary to compare and analyze how instructional content related to investigative learning is dealt with in art education when examining how school libraries can better support investigative learning in art classes. To compare and analyze how the content of investigative learning is dealt with in art education, it is useful to consult the Table of Instructional Systems for Learning to Use Information Resources (edited by the Japan School Library Association in 2019 on what kind of instruction should be given to students to support their learning including investigative learning, hereinafter referred to as the Guidelines), which shows the instructional content that is considered necessary in the process of investigative learning. This is a successor to "Connecting Information to Learning: A Table of Instructional Systems for Learning Using Information and Media," which was introduced in the textbook Learning Instruction and School Libraries (Saito et al., 2015). This 
book suggests that one of the subjects required to become a teacher librarian, is the systematization of the information literacy, a skill necessary to solve problems or issues.

Regarding the developmental characteristics of junior high-aged and older students, Fukumoto and Mizushima (2009) show the correspondence between developmental characteristics and practical issues in art learning and state that having an "objective view," "understanding of aesthetic and plastic elements," and "basic interest in the subject of appreciation" are characteristics of students from the fifth grade to the first grade of junior high school. In addition, they argue that the "development of observation skills," "development of intellectual expression based on logical thinking," "understanding of the effects of expression," "development of planning," and "development of appreciation (verbal criticism)" are characteristics of students from the second year of junior high though the first year of high school. Thus, since the abilities necessary for investigative learning are developed in these stages, this study focused on art education at the junior and senior high school levels. It is important to clarify how the instructional content related to investigative learning is dealt with in art education at these levels.

\section{Research Problem}

There is little research on how school libraries, which play a central role in supporting investigative learning, particularly support investigative learning in art classes. This study aims to analyze school libraries' ability to support investigative learning in art classes and propose methods for doing so.

\section{Methodology}

Survey Targets

We analyzed Designated School Project for Curriculum Research reports regarding art classes from the past five school years (April 2015 to March 2020) at the junior and senior high school levels. The Designated School Project for Curriculum Research is a practical project conducted by the National Institute for Educational Policy Research (NIER), Japan's representative research institution in education policy, in designated schools and regions to ensure the smooth implementation of curricula based on the Courses of Study. Each report contained a summary of the classes taught throughout the year at each school. The current study included 10 junior high school and 15 senior high school reports. At the senior high school level, art is divided into "art" and "crafts"; therefore, both were included in the analysis. These reports were then compared with the Guidelines and analyzed to discern how school libraries can support the objectives in art education.

\section{Survey Items}

The items surveyed in this study consist of the following. The Guidelines comprise four stages: I. Task setting, II. Use of media, III. Utilizing information, and IV. Summarizing and transmitting information. The contents are divided into lower elementary school, middle 
elementary school, upper elementary school, junior high school, and senior high school. In this study, we investigated the junior and senior high school levels, in order to compare them with art classes taught in junior and senior high schools, and the crafts classes offered in high schools. Each stage has further subcategories, which can be applied to investigative learning. More specifically, there were 12 "items of instruction," made up of 22 subcategories ("instructional contents"). Among these, there are 27 examples, some of which are "items of instruction" and other that are "instructional contents."

\section{Procedures}

We compared the content of the art classes in the reports with the content in the Guidelines. We extracted learning elements (what art teachers aimed to have the students learn in classes) from the reports and divided them into four categories: formative elements and techniques (Type A), culture and history (Type B), relationship between art and society and functions of works (Type C), and ideas for or concepts about the work (Type D). As mentioned in the Survey Targets section, each report contained a summary of the classes taught throughout the year at each school. Therefore, some reports contained more than one type of class. The contents of the classes were then compared with the Guidelines. The parts in which the instruction followed the Guidelines were extracted for each learning element.

\section{Findings}

Table 1 shows a comparison of the Table of Instructional System for Learning with Information Resources (as mentioned in the Literature Review, hereinafter, "the Guidelines") and art education. After comparing and categorizing the content of art education at junior and senior high school levels with the Guidelines, it was determined that all four stages of the Guidelines were conducted in art education. The instructional content for Types A, B, C, and D were all found in Stage II's items of instruction, "Utilizing different types and characteristics of media." These results are shown in greater detail below.

\section{Table 1}

Comparing the "Table of Instructional System for Learning with Information Resources" (the Guidelines) and Art Education

\begin{tabular}{|c|c|c|c|c|c|}
\hline \multirow[t]{2}{*}{$\begin{array}{l}\text { Stages in the } \\
\text { Guidelines }\end{array}$} & \multirow[t]{2}{*}{$\begin{array}{l}\text { Items of } \\
\text { instruction in the } \\
\text { Guidelines }\end{array}$} & $\begin{array}{l}\text { Type A: Formative } \\
\text { elements and } \\
\text { techniques }\end{array}$ & $\begin{array}{l}\text { Type B: Culture } \\
\text { and history }\end{array}$ & $\begin{array}{l}\text { Type C: } \\
\text { Relationship } \\
\text { between art and } \\
\text { society, functions }\end{array}$ & $\begin{array}{l}\text { Type D: Ideas or } \\
\text { concepts on the } \\
\text { work }\end{array}$ \\
\hline & & \multicolumn{4}{|c|}{$\begin{array}{l}\text { Instructional contents and examples appearing in the reports which correspond to the } \\
\text { contents and examples in the Guidelines }\end{array}$} \\
\hline $\begin{array}{l}\text { I . Task } \\
\text { setting }\end{array}$ & $\begin{array}{l}\text { 1-1 Setting the } \\
\text { task }\end{array}$ & & & $\begin{array}{l}\diamond \text { Writing down the } \\
\text { reason for task } \\
\text { setting }\end{array}$ & $\begin{array}{l}\diamond \text { Writing down the } \\
\text { reason for task } \\
\text { setting }\end{array}$ \\
\hline
\end{tabular}




\begin{tabular}{|c|c|c|c|c|c|}
\hline & $\begin{array}{l}\text { 1-2 Making a } \\
\text { learning plan }\end{array}$ & & & & $\begin{array}{l}\diamond \text { Having a learning } \\
\text { perspective }\end{array}$ \\
\hline \multirow[t]{3}{*}{$\begin{array}{l}\text { II. Use of } \\
\text { media }\end{array}$} & $\begin{array}{l}\text { 2-1 Using the } \\
\text { school library } \\
\text { effectively }\end{array}$ & & & & $\begin{array}{l}\star \text { (no specific } \\
\text { examples) }\end{array}$ \\
\hline & $\begin{array}{l}2-2 \text { Using } \\
\text { various facilities } \\
\text { according to } \\
\text { their purpose }\end{array}$ & *Museums & & & ${ }^{*}$ Museums \\
\hline & $\begin{array}{l}\text { 2-3 Utilizing the } \\
\text { different types } \\
\text { and } \\
\text { characteristics of } \\
\text { media }\end{array}$ & $\begin{array}{l}* \text { Digital media } \\
* \text { Human sources, } \\
\text { fieldwork } \\
\star \text { Reproductions of } \\
\text { works } \\
\star \text { Real works } \\
\star \text { Natural objects } \\
\star \text { Art cards }\end{array}$ & $\begin{array}{l}* \text { Digital media } \\
* \text { Human sources } \\
\star \text { Real works } \\
\star \text { Video media }\end{array}$ & $\begin{array}{l}* \text { Digital media } \\
* \text { Human sources, } \\
\text { fieldwork } \\
\star \text { Real works } \\
\star \text { Photos }\end{array}$ & $\begin{array}{l}* \text { Books, reference } \\
\text { books } \\
* \text { Digital media } \\
* \text { Human sources } \\
\star \text { Reproductions of } \\
\text { works } \\
\star \text { Real works } \\
\star \text { Natural objects } \\
\star \text { Art cards } \\
\star \text { Various media }\end{array}$ \\
\hline \multirow[t]{4}{*}{$\begin{array}{l}\text { III. Utilizing } \\
\text { information }\end{array}$} & $\begin{array}{l}\text { 3-1 Collecting } \\
\text { information }\end{array}$ & $\begin{array}{l}\text { *Books, reference } \\
\text { books } \\
\text { *Digital media }\end{array}$ & $\begin{array}{l}\text { *Books, reference } \\
\text { books }\end{array}$ & & $\begin{array}{l}\text { *Books, reference } \\
\text { books } \\
\text { *Digital media }\end{array}$ \\
\hline & $\begin{array}{l}\text { 3-2 Recording } \\
\text { information }\end{array}$ & & & & $\begin{array}{l}\diamond \text { Recording with } \\
\text { information devices }\end{array}$ \\
\hline & $\begin{array}{l}\text { 3-3 Analyzing } \\
\text { and evaluating } \\
\text { information }\end{array}$ & & & & \\
\hline & $\begin{array}{l}\text { 3-4 Knowing } \\
\text { how to use } \\
\text { information }\end{array}$ & & & & $\begin{array}{l}\text { *Information on the } \\
\text { Internet } \\
\text { *Copyright, how to } \\
\text { cite, how to write the } \\
\text { source }\end{array}$ \\
\hline \multirow[t]{2}{*}{$\begin{array}{l}\text { IV. } \\
\text { Summarizing } \\
\text { and } \\
\text { transmitting } \\
\text { information }\end{array}$} & $\begin{array}{l}\text { 4-1 Summarizing } \\
\text { learning } \\
\text { outcomes }\end{array}$ & $\begin{array}{l}\diamond \text { Summarizing based } \\
\text { on the persons and } \\
\text { purpose } \\
\diamond \text { Documenting the } \\
\text { process of problem } \\
\text { solving } \\
* \text { Tablet devices, } \\
\text { electronic blackboards, } \\
\text { computers }\end{array}$ & & & $\begin{array}{l}\diamond \text { Summarizing } \\
\text { based on the persons } \\
\text { and purpose } \\
\diamond \text { Documenting the } \\
\text { process of problem } \\
\text { solving } \\
\text { *Tablet devices, } \\
\text { electronic } \\
\text { blackboards, } \\
\text { computers }\end{array}$ \\
\hline & $\begin{array}{l}\text { 4-2 Presenting } \\
\text { learning } \\
\text { outcomes }\end{array}$ & & & $\begin{array}{l}\star \text { (no specific } \\
\text { examples) }\end{array}$ & $\begin{array}{l}\star \text { (no specific } \\
\text { examples) }\end{array}$ \\
\hline
\end{tabular}




\begin{tabular}{|c|c|c|}
\hline $\begin{array}{l}\text { 4-3 Evaluating } \\
\text { learning } \\
\text { processes and } \\
\text { outcomes } \\
\text { (self-evaluation } \\
\text { and mutual } \\
\text { evaluation) }\end{array}$ & $\begin{array}{l}\diamond \text { Verifying the validity } \\
\text { of task setting and the } \\
\text { learning plan }\end{array}$ & $\begin{array}{l}\diamond \text { Verifying the } \\
\text { validity of task } \\
\text { setting and the } \\
\text { learning plan }\end{array}$ \\
\hline
\end{tabular}

The 22 small categories and 27 items in the middle category in the Guidelines not found in the surveyed classes are not shown in Table 1.

\section{Task Setting}

First, we analyzed the Guidelines' first stage, task setting. One of the subcategories of this stage is the item of instruction "setting the task." A further subcategory is "writing down the reason for task setting" As an example of this activity in the reports on Type C and D, under the goal of "clarifying the purpose of production," students were asked to "set up a design concept based on the contents and target audience, and to work on idea sketches while considering the purpose, function, and beauty from the perspective of the purchaser" (senior high art class) (NIER, 2020c). The activity corresponding to another item of instruction, "making a plan for learning," was instructed in the report on a Type D class (senior high art class). In one example, one of the objectives was to "organize one's own thoughts and clarify the subject," while the sub-item "having a learning perspective," was conducted. However, the other sub-item, "thinking of ways to investigate," was not found in the reports analyzed in this study.

\section{Use of Media}

Next, the second stage, "use of media," has three items of instruction, "using the school library effectively," "using various facilities according to their purpose," and "utilizing the different types and characteristics of media." In the report of Type A and D noted the activity of "using various facilities according to their purpose." As an example of various facilities, "museums" were mentioned. In this case, the goal was to "deepen students' thinking step by step in creating a subject" (junior high art class) (NIER, 2020b).

Additionally, the activity "utilizing the different types and characteristics of media" was noted in all examples of class Types A, B, C, and D. In one example, from a junior high school art class, the students were asked to "view slides related to various types of light, such as light itself, its shadows, and materials that change the light," and to "exchange opinions with their groups about the properties and effects of light, and to search for light they find attractive." Another example asked students to view "background pictures of animated films" (senior high art class) (NIER, 2020c). As for the activity "using the school library effectively," although the specific examples 
listed in the Guidelines were not reported, there was one senior high craft class (a Type D class) in which the teacher asked the students to "think about the ideas and concepts of craft works with an awareness of other people's viewpoints." Therefore, we added a star mark to the relevant field in Table 1 to indicate "example(s) not covered in the Guidelines, but for which school libraries are considered to have the ability to provide support."

\section{Utilizing Information}

The third stage was "utilizing information." This stage has four items of instruction: "collecting information," "recording information," "analyzing and evaluating information," and "knowing how to use information." Reports from class Types A, B, and D each noted the activity of "collecting information.". In Type A and D classes, "digital media" were also dealt with, and it was reported that, "in order to increase the effectiveness of information use, we worked on the maintenance of the Internet environment and tablet terminals in the classroom, as well as preparing viewing materials using catalogs and flyers of special exhibitions at museums" (NIER, 2020c). The activity "recording information" was instructed in a Type D class, as was "recording with information devices." Additionally, a Type D class reported the activity of "knowing how to use information," and the specific contents to be taught to the students were "information on the Internet" and "copyright, how to cite, how to write the source." We did not find any classes in which items of instruction corresponding to "analyzing and evaluating information" were noted in the analyzed reports.

\section{Summarizing and Transmitting Information}

Finally, we analyzed the fourth stage, "summarizing and transmitting information." This stage has three items of instruction: "summarizing learning outcomes," "presenting learning outcomes," and "evaluating learning processes and outcomes (self-evaluation and mutual evaluation)." In the report on Type A and D, the items of instruction of "summarizing learning outcomes" were noted, and the specific contents were "summarizing in a method according to the persons and purpose" and "documenting the process of problem solving." In the report on Type A and D, the item of instruction of "evaluating learning processes and outcomes (self-evaluation and mutual evaluation)" was noted, as was "verifying the validity of task setting and learning plan." In one example, students were asked to "find and take pictures of the scenery they wanted to see with their family, friends, or other loved ones in the town where they lived or on their way to school, and then projected the pictures on a screen." After that, "each group of four or five students placed a printed work in the center of the prepared large sheet of paper, wrote their opinions on sticky notes around it and critiqued each other's work." As for the activity "presenting learning outcomes," although the specific examples listed in the Guidelines were not reported, there was a class in which students made presentations. Therefore, we added a star mark to the relevant field of Table 1 to indicate "example(s) not covered in the Guidelines, but for which school libraries are considered to have the ability to provide support." Specifically, in the report corresponding to Types C and D (high school art class), students were asked to "feel 
the diversity of images that public art gives to people by having them summarize, describe, and present their own thoughts from the works and by having them listen to the opinions of other students" (NIER, 2020c).

\section{Examples of Direct References to "Investigate" and the "School Library"}

The reports included the following examples in which students engaged in an investigative activity. In one junior high report, there was an example of students being asked to research and summarize the similarities and differences between Japanese and foreign art. In a high school art class, students were asked to research the elements necessary to sell a product, such as the color and design to be used in the packaging of a confectionary product and the best method for selling it. In a high school craft class, students were asked to research traditional crafts.

Among the classes in which school libraries were mentioned in the report, one class had the goal "to be able to think about the ideas and concepts of craft works with an awareness of the perspectives of others." (NIER, 2020d) In this class, the art teacher cooperated with the librarian to collect materials and practice the class, prepared a place in the classroom where students browse materials, and used ICT equipment to search and keep records, etc., to prepare reference materials and the classroom environment.

In order to "enhance appreciation activities," it was reported that the art teacher "collaborated with the librarian, collected materials related to crafts, and created an environment where students can access many materials at any time during class."

With the above in mind, it was determined that all four stages of the Guidelines were featured in art education. As for the item of instruction in Stage II, "utilizing different types and characteristics of media," it was found in all types of classes, A, B, C, and D.

\section{Discussion}

These results suggest that school libraries have the potential to support all stages of investigative learning in art classes. Regarding "Utilizing different types and characteristics of media," which was the most frequently reported item from the Guidelines, school libraries can be active in supporting students' investigative learning. The results also indicate that school libraries are considered capable of providing active learning support, especially for instructing students on how to "utilize different types and characteristics of media" in Stage II and in Type D classes. In view of the large number of Type D classes reported, we can also conclude that there is a high probability that school libraries can support students when they are thinking about ideas or concepts in their work (i.e., during the introduction of the class).

Regarding "Utilizing different types and characteristics of media," which was the most frequently reported item from the Guidelines, school libraries can be active in supporting 
students' investigative learning. It is necessary to prepare and support students' access to various media as forms of support in the stage of "utilizing the different types and characteristics of media," which was the most-frequently reported activity. Additionally, creating lists of materials that could be used in art classes or pathfinders are effective ways to support students' investigative learning. In a questionnaire survey conducted among junior high school art teachers, real objects or real works, replicas, and DVDs were relatively frequently cited as teaching materials that teachers wanted to use but could not (Kuroda \& Suzuki, 2013). It is recommended that school libraries, in cooperation with museums and public libraries, actively collect information on whether there are materials, including not only books and audiovisual materials, but also real objects/works and replicas, that schools can borrow and that are relevant to each subject of the class, so that students can make use of cultural resources outside the school in art classes. The Commentary on the Courses of Study mentions that "it is necessary to use reproductions that are close to the real objects in terms of size and materiality, and printed materials that show the characteristics of the work (omitted), in order to promote effective instruction in appreciation" (MEXT, 2017). It also instructs that "the use of books for appreciation and visual materials in school libraries should be promoted."

Notably, the reports did not include the following: the item of instruction from instructional contents Stage I, "thinking of ways to investigate," the Stage II example "computer catalogs," or the "reference services," of the school library, or the item of instruction from Stage III, "analyzing and evaluating information." Since the school library can provide active support in these processes, art teachers should work with the librarian to use the school library in these activities. Additionally, even for learning activities that are infrequently practiced per current reports, school libraries have the ability to support students' investigative learning. As shown, they can more actively support students' investigative learning in classes that compare Japanese and foreign art and explore the elements of product design and traditional crafts.

In Alberta, Canada, the Ministry of Education has developed a unique "inquiry model" that encourages students to engage in metacognitive activities and has published a guide for teachers and librarians, Focus on Inquiry (Alberta Government, 2004), which specifically explains how to teach the model and encourages the teaching of inquiry-focused learning across the curriculum (Adachi, 2008). In this model, the six processes of planning, retrieving, processing, creating, sharing, and evaluating are arranged in a circle in the shape of a puzzle, with each process touching the "reflecting on the process" section in the middle. That each process is connected to the middle reflection expresses the importance of proceeding with inquiry while also taking time for reflection. It is also necessary to create a process model of investigative learning in art education that has a link with this model, and to organize the contents that school libraries should support in each process. 
The "Systematic Table for Teaching how to Learn to Use Information Resources" is a guide for teaching students according to their developmental stages, so that they can learn how to learn. Such guidance on "how to learn," which is an essential element of information literacy, is also taken up in the art class' framework, so we must assume some level of cooperation with art classes for teaching how to learn using information resources. By contrast, some knowledge and skills in the table are not dealt with directly in art classes, but are, instead, prerequisites. They are part of the knowledge and skills required for investigative learning in art classes, so school libraries are expected to play a central role in developing students' information literacy through investigative learning. School libraries should strive to enhance their functions as learning and information centers that promote students' use of various media in collecting and selecting information, with teacher librarians taking a leading role in this process (MEXT, 2011). Consequently, it is meaningful for school library staff and art teachers to cooperate and provide guidance to all students. Therefore, it is significant for school libraries and art teachers to collaborate and share their roles in art classes in order to realize an effective instruction for students.

\section{Implications and Conclusions}

The purposes of this study were to analyze school libraries' ability to support investigative learning in art classes and propose methods for doing so. A comparative analysis of reports of art classes and instructional content related to investigative learning suggested that school libraries can support all stages of students' investigative learning in art classes. There were reports on classes in which students researched Japanese and foreign art, product package design, and traditional crafts. The most frequently reported learning activity was "Utilizing different types and characteristics of media;" however, it is thought that school libraries can actively support students' investigative learning at all stages, such as with instructional items that include "thinking of ways to investigate/consider strategies and measures to solve problems" or "analyzing and evaluating information," which were not reported in our analysis.

In order to deepen students' learning, it is necessary for school libraries to work closely with art teachers to consider how, and at what stage of the investigative learning process, they can support students. The most frequent report was about a class in which students learned about Type D of "ideas or concepts on the work." Therefore, there is a high probability that school libraries can support students when they are thinking about ideas or concepts in their work (i.e., during the introduction of the class). It is necessary to prepare and support students' access to various media as forms of support in the stage of "utilizing the different types and characteristics of media," which was the most-frequently reported. Partnerships with museums and public libraries are also required to ensure that students have access to various media. Additionally, creating lists of materials that could be used in art classes or pathfinders are effective ways to support students' investigative learning. In collaboration with art teachers, school libraries must work to prepare and support students' access to various media, in order to deepen their 
investigative learning. It is also necessary to create a process model of investigative learning in art education, and to organize the contents that school libraries should support in each process.

\section{References}

Adachi, M. (2008). "Tankyu” o Sokushinsuru Gakko Toshokan (School Libraries to Promote "Inquiry"). Current Awareness 297, 6-9.

Alberta Government. (2004). Focus on Inquiry: A Teacher's Guide to Implementing Inquiry-based Learning. Retrieved from https://open.alberta.ca/dataset/032c67af-325c-4039-a0f3-100f44306910/resource/b75856 34-fabe-4488-a836-af22f1cbab2a/download/29065832004focusoninquiry.pdf.

Efland, A. D. (2003). Art and Cognition: Integrating the Visual Arts in the Curriculum. Teachers College Press.

Fukuda, Seiji. (2019). Kokusai Baccalaureate o Sasaeru Gakko Toshokan (School Libraries to Support the International Baccalaureate Education). Gakko Toshokan (School Library), no. $824,36-38$.

Fukumoto, K., \& Mizushima, N. (Eds.). (2009). Heisei 20nen Kaitei Chugakko Kyoiku Katei Koza Bijutsu (Art Curriculum at Junior High Schools, Revised in 2008). Gyosei.

International Baccalaureate. (2021a). Arts. Retrieved from https://www.ibo.org/programmes/middle-years-programme/curriculum/arts/.

International Baccalaureate. (2021b). The Arts. Retrieved from https:/www.ibo.org/programmes/diploma-programme/curriculum/the-arts/.

Japan School Library Association. (2019). Joho Shigen o Katsuyosuru Manabi no Shido Taikeihyo (Table of Instructional Strategies for Learning with Information Resources). Retrieved from https://www.j-sla.or.jp/pdfs/20190101manabinosidoutaikeihyou.pdf.

Kasuga, A.; Izumiya, Y.; Ohashi, I. et al. (2016a). Bijutsu 1 (Art Textbookfor Seventh Grade), Osaka: Nihon Bunkyo Shuppan.

Kasuga, A.; Izumiya, Y.; Ohashi, I. et al. (2016b). Bijutsu 2\&3 Ge (Art Textbook for Eighth and Ninth Grades: 2), Osaka: Nihon Bunkyo Shuppan.

Kasuga, A.; Izumiya, Y.; Ohashi, I. et al. (2016c). Bijutsu 2\&3 Jo (Art Textbook for Eighth and Ninth Grades: 1), Osaka: Nihon Bunkyo Shuppan.

Kuroda, A. \& Suzuki, K. (2013). Chugakko Bijutsuka no Kansho Gakushu niokeru Kyozai Kyogu no Riyo Jokyo oyobi Kadai (The Use of Teaching Materials for Art Appreciation Lessons in Junior High School and Related Issues). Bijutsu Kyoiku (Art Education), no. 297, 24-32.

Kuroda, A., Suzuki, K. \& Hirakue, Y. (2015). Gakko Toshokan niokeru Chugakko Bijutsuka no Kansho Gakushu eno Shien ni Kansuru Chosa (A Survey on Support for Art Appreciation Learning at Junior High Schools by School Libraries). Dai 63kai Nihon Toshokan Joho Gakkai Kenkyu Taikai Happyo Ronbunshu (Proceedings of the 63rd Annual Conference of the Japan Society of Library and Information Science), 77-80. 
Ministry of Education, Culture, Sports, Science and Technology. (2017). Chugakko Gakushu Shido Yoryo Kaisetsu Bijutsuhen (Heisei 29nen Kokuji) (Commentary on the Courses of Study for Art Classes at Junior High Schools [Published in 2017]). Nihon Bunkyo Shuppan.

Ministry of Education, Culture, Sports, Science and Technology. (2018). Koto Gakko Gakushu Shido Yoryo (Heisei 30nen Kokuji) Kaisetsu Geijutsu(Ongaku Bijutsu Kogei Shodo) hen (Commentary on the Courses of Study for Art Classes at Senior High Schools [Published in 2018] [Music, Art, Crafts, Japanese Calligraphy]). Nihon Bunkyo Shuppan.

Ministry of Education, Culture, Sports, Science and Technology. (2011). Kyoiku no Johoka

Vision (Informatization of Education). Retrieved from http://www.mext.go.jp/component/a_menu/education/micro_detail/_icsFiles/afieldfile/2 017/06/26/1305484_01_1.pdf.

Murakami, H.; Ohashi, I.; Sato, K. et al. (2021a). Bijutsu 1 (Art Textbook for Seventh Grade), Osaka: Nihon Bunkyo Shuppan.

Murakami, H.; Ohashi, I.; Sato, K. et al. (2021b). Bijutsu 2\&3 Ge (Art Textbook for Eighth and Ninth Grades: 2), Osaka: Nihon Bunkyo Shuppan.

Murakami, H.; Ohashi, I.; Sato, K. et al. (2021c). Bijutsu 2\&3 Jo (Art Textbook for Eighth and Ninth Grades: 1), Osaka: Nihon Bunkyo Shuppan.

National Institute for Educational Policy Research. (2020a). Kyoiku Katei Kenkyu Shiteiko Jigyo Kenkyu Seika Hokokusho (Reports on the Designated School Project for Curriculum Research). Retrieved from https://www.nier.go.jp/kaihatsu/shiteikou.html.

National Institute for Educational Policy Research. (2020b). Kenkyu Seika Hokokusho Chugakko Bijutsu (Report Summaries of Art Classes at Junior High Schools). Retrieved from https://www.nier.go.jp/kaihatsu/shiteikou/shiteikou-seikahoukoku-mid_bijyut.html.

National Institute for Educational Policy Research. (2020c). Kenkyu Seika Hokokusho Koto Gakko Geijutsu (Bijutsu) (Report Summaries of Art Classes at Senior High Schools). Retrieved from https://www.nier.go.jp/kaihatsu/shiteikou/shiteikou-seikahoukoku-hig_geij_bijyut.html.

National Institute for Educational Policy Research. (2020d). Kenkyu Seika Hokokusho Koto Gakko Geijutsu (Kogei) (Report Summaries of Craft Classes at Senior High Schools). Retrieved from https://www.nier.go.jp/kaihatsu/shiteikou/shiteikou-seikahoukoku-hig_geij_kogei.html.

Nihon Zokei Kyoiku Kenkyukai. (2016a). Bijutsu 1 (Art Textbook for Seventh Grade), Tokyo: Kairyudo Shuppan.

Nihon Zokei Kyoiku Kenkyukai. (2016b). Bijutsu 2 \& 3 (Art Textbook for Eighth and Ninth Grades), Tokyo: Kairyudo Shuppan.

Nihon Zokei Kyoiku Kenkyukai. (2021a). Bijutsu 1 (Art Textbook for Seventh Grade), Tokyo: Kairyudo Shuppan.

Nihon Zokei Kyoiku Kenkyukai. (2021b). Bijutsu 2 \& 3 (Art Textbook for Eighth and Ninth Grades), Tokyo: Kairyudo Shuppan. 
Sakai, T.; Ueno, K.; Okada, M. et al. (2016a). Bijutsu 1 (Art Textbookfor Seventh Grade), Tokyo: Mitsumura Tosho.

Sakai, T.; Ueno, K.; Okada, M. et al. (2016b). Bijutsu 2 \& 3 (Art Textbook for Eighth and Ninth Grades), Tokyo: Mitsumura Tosho.

Sakai, T.; Ida, M., Ueno, K. et al. (2021a). Bijutsu 1 (Art Textbookfor Seventh Grade), Tokyo: Mitsumura Tosho.

Sakai, T.; Ida, M., Ueno, K. et al. (2021b). Bijutsu $2 \& 3$ (Art Textbook for Eighth and Ninth Grades), Tokyo: Mitsumura Tosho.

Saito, Y., Eryu, T., Tominaga, K. \& Muraki, M. (2015). Gakushu Shido to Gakko Toshokan (Instruction for Learning in the School Library). Jusonbo. 